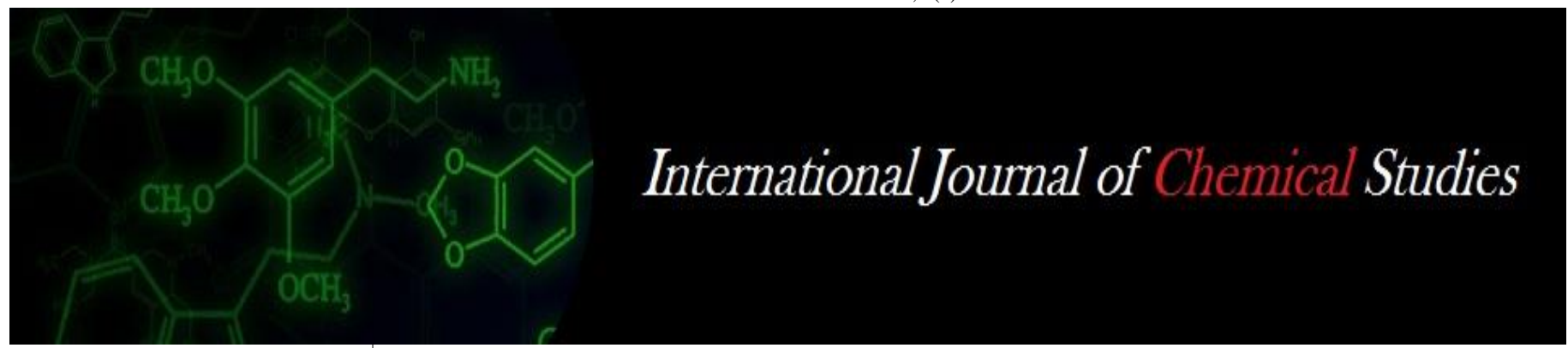

P-ISSN: 2349-8528

E-ISSN: 2321-4902

www.chemijournal.com

IJCS 2020; 8(4): 3402-3404

(C) 2020 IJCS

Received: 01-05-2020

Accepted: 03-06-2020

\section{Purabi Deka}

Department of Veterinary

Pathology, Lakhimpur College of

Veterinary Science, Assam

Agricultural University,

Joyhing, North Lakhimpur,

Assam, India

\section{RK Sharma}

Professor, Department of

Microbiology, College of

Veterinary Science, Assam

Agricultural University,

Khanapara, Guwahati, Assam,

India

\section{N Pathak}

Assistant Professor, Department of Veterinary Pathology,

Lakhimpur College of Veterinary

Science, Assam Agricultural

University, Joyhing, North

Lakhimpur, Assam, India
Corresponding Author:

Purabi Deka

Department of Veterinary

Pathology, Lakhimpur College of

Veterinary Science, Assam

Agricultural University,

Joyhing, North Lakhimpur,

Assam, India

\section{Comparision of iron-regulated outer membrane proteins (IrOMP) and iron-sufficient outer membrane proteins (IsOMP) of Pasteurella multocida strains of porcine origin}

\author{
Purabi Deka, RK Sharma and N Pathak
}

DOI: $\underline{\text { https://doi.org/10.22271/chemi.2020.v8.i4aq.10176 }}$

\begin{abstract}
An investigation was carried out to compare the effect of growth of $P$. multocida type A of pig origin in iron restricted and in iron sufficient media on the basis of their outer membrane protein extract. Pasteurella multocida serotype A was cultured in two ways. In one process only BHI medium was used and on the other process same medium was used which was supplemented with 2, 2'- Dipyridyl (ironrestricted medium). Both these cultures were used to obtain Outer Membrane Proteins (OMPs) by extraction of bacterial cells with 1\% Sarcosyl. Separation of the OMPs in SDS-PAGE showed that OMPs were mixture of protein fraction with molecular weight ranging from 110 to $22.6 \mathrm{kDa}$ in case of ironrestricted OMP and 47.3 to $29.9 \mathrm{kDa}$ in case of iron sufficient OMP. The OMP with molecular masses $29.9 \mathrm{kDa}$ grew in both iron-restricted as well as in iron sufficient medium.
\end{abstract}

Keywords: Pasteurella multocida, BHI medium, outer membrane proteins, SDS-Page

\section{Introduction}

Pasteurella multocida is widely distributed throughout the world and is known to cause a variety of diseases in animals and birds. P. multocida Capsular type A is an etiological agent of swine pneumonic pasteurellosis, which is a common disease of pigs. The pathogenicity of $P$. multocida is associated with various virulence factors (Harper et al., 2006) ${ }^{[1]}$. The key factors which play important role in pathogenesis of pasteurellosis include the capsule and lipopolysaccharide, adhesions, toxins, siderophores, sialidases and outer membrane proteins (e.g., OmpA, OmpH, Oma87 and PlpB) (Martin and Ferri, 1993) ${ }^{[2]}$. The outer membrane proteins (OMPs) play a significant role in the pathogenesis of pasteurellosis (Srivastava et al., 1998) ${ }^{[3]}$. Several OMPs are immunogens and the antibodies produced against these OMPs demonstrate a strong protective action. Such antigens may be used as components of subunit vaccines.

Iron is essential for bacterial growth and replication and plays a role in the establishment and progression of infection. To survive and grow under iron limiting conditions bacteria require an efficient iron sequestering system. Several iron uptake systems of pathogenic bacteria have been identified (Wooldridge and Williams, 1993) ${ }^{[4]}$. One system involves the secretion of siderophores capable of removing iron from iron-binding glycoproteins and the expression of OMPs that are receptors for the iron-siderophore complex (Neilands, 1993) ${ }^{[5]}$. Outer membrane proteins grown in iron restricted medium are found to be having higher molecular weight protein fraction as compared to OMPs from iron sufficient media. Veken et al. (1996) ${ }^{[6]}$ reported that OMPs of certain serotype of $P$. multocida when grown under iron-deficient conditions showed several iron-repressible membrane polypeptides seroreactive against $P$. multocida antibodies. It was believed that such iron-repressible membrane polypeptides found to be more immunogenic and could be a candidate for developing improved vaccine. The aim of this present study was to compare the effect of growth of $P$. multocida type A of pig origin in iron restricted and iron sufficient media on the basis of their outer membrane protein profile extraction. 


\section{Material and Methods}

Bacterial isolates and growth conditions: One liophilized isolate of $P$. multocida was obtained from the repository of All India Network Project on Haemorrhagic Septicaemia, Department of Microbiology, College of Veterinary Science, Assam Agricultural University, Khanapara, Guwahati. Pasteurella multocida isolate was revived by inoculating on $5 \%$ sheep blood (Collines and Lyne, 1970) ${ }^{[7]}$ at $37^{\circ} \mathrm{C}$ for overnight.

Preparation of OMPs from $\boldsymbol{P}$. multocida strains for SDSPage: The strain was cultured on two Brain Heart Infusion (BHI) broth preparation- (i) Iron sufficient BHI broth and (ii) Iron restricted BHI broth containing an iron chelating agent, $150 \mu \mathrm{M}$ of 2, 2'- Dipyridyl (Kharb and Charan, 2010) ${ }^{[8]}$ and incubated in shaking incubator using $120 \mathrm{rpm}$ at $37^{\circ} \mathrm{C}$ over night. The overnight cultures were centrifuged at $5000 \mathrm{x} \mathrm{g}$ for 15 minutes at $4^{\circ} \mathrm{C}$. The supernatant was decanted and the palleted bacteria was washed thrice in PBS $(\mathrm{pH} 7.4)$. The washed bacterial cells were resuspended in $10 \mathrm{mM}$ HEPES buffer, $\mathrm{pH}$ 7.4. The cell suspension of iron sufficient and iron restricted media was sonicated separately. After sonication, centrifugation was done at $5000 \mathrm{x}$ g for 20 minutes at $4{ }^{\circ} \mathrm{C}$. The supernatant was ultra centrifuged at $100000 \times \mathrm{g}$ for 60 minutes at $4{ }^{\circ} \mathrm{C}$. After that, the pellet was resuspended in $2 \%$ sodium lauryl sarcocinate prepared in 10mM HEPES buffer and incubated at $22^{\circ} \mathrm{C}$ for 60 minutes. After incubation, the suspension was ultracentrifuged at $100000 \mathrm{x}$ g for 60 minutes at $4{ }^{\circ} \mathrm{C}$. The pellet was washed twice with sterile distilled water and the final pellet was resuspended in 0.1MM PBS ( $\mathrm{pH} 7.4)$.

Estimation of protein concentration of OMP: The OD value protein of iron sufficient OMP (IsOMP) and iron restricted OMP (IrOMP) extract were determined by spectrophotometer at $660 \mathrm{~nm}$.

Separation in SDS-PAGE: Electrophoretical separation of the proteins of $P$. multocida strains was performed in $12 \%$ polyacrylamide gels according to the procedure described by Laemmli (1970) ${ }^{[9]}$. The separation was carried out at $20 \mathrm{~V}$ constant voltage, at room temperature until the dye front (bromophenol blue) was as close as $1 \mathrm{~mm}$ to the end of gel. The gels were stained with Coomassie for overnight. After staining, gel was distained with distaining solution.

\section{Results and Discussion}

Pasteurella multocida capsuler type A which was cultured in BHI broth with $150 \mu \mathrm{M}$ of 2, 2- Dipyridyl showed a reduced growth during over night incubation in comparison to the culture which was grown in BHI broth alone. The protein concentration of $P$. multocida grown in iron sufficient media was $0.104 \mathrm{mg} / \mathrm{ml}$ and in iron restricted media it was 0.240 $\mathrm{mg} / \mathrm{ml}$. These findings revealed that OMP extracted from iron restricted medium was more than that of iron sufficient medium. In a study in sheep and goat Nagpal et al. (2013) ${ }^{[10]}$ reported higher concentration of OMP $(225 \mu \mathrm{g} / \mathrm{ml}$ broth $)$. The difference in OMP concentration might be due to the variation in bacterial strain and OMP extraction procedure.

Protein profile of cells grown in iron sufficient as well as in iron restricted media are shown in Fig.1. A total of 10 nos. major bands were seen in cells of $P$. multocida grown in BHI broth with Dipyridyl. These were $110 \mathrm{kDa}, 99 \mathrm{kDa}, 75 \mathrm{kDa}$, 63.3 kDa, 54.6 kDa, 46.6 kDa, 40.9 kDa, 37.5 kDa, 29.9 kDa and $22.6 \mathrm{kDa}$. The corresponding bands for iron sufficient
OMPs were 47.3 kDa, 41.3 kDa and 29.9 kDa. Depend on band intensity, 5 polypeptide with molecular weight of 75 $\mathrm{kDa}, 40.9 \mathrm{kDa}, 37.5 \mathrm{kDa}, 29.9 \mathrm{kDa}$ and $22.6 \mathrm{kDa}$ for IrOMP and one polypeptide with molecular weight of $47.3 \mathrm{kDa}$ for IsOMP were considered to be major OMP. BorkowskaOpacka and Kedrak (2002) ${ }^{[11]}$ also found OMP extract of $P$. multocida showing protein band ranging from 112 to $22 \mathrm{kDa}$ for IrOMP and 86 to $22 \mathrm{kDa}$ for IsOMP. Choi-Kim et al. (1991) ${ }^{[12]}$ reported $34 \mathrm{kDa}$ protien fraction to be major OMP for serotype A while Zhang et al. (1994) ${ }^{[13]}$ reported $35.5 \mathrm{kDa}$ to be major OMP.

The OMPs with molecular masses $29.9 \mathrm{kDa}$ grew in both iron-restricted and in iron sufficient medium. Srivastava et al. (1998) ${ }^{[3]}$ also reported $22 \mathrm{kDa}$ major protein band which was common for both IrOMP and IsOMP. The Difference in molecular size of OMP might be due to the strain variation and extraction procedure.

SDS-PAGE result showed the presence of protein fraction of high molecular weights $110 \mathrm{kDa}, 99 \mathrm{kDa}, 75 \mathrm{kDa}, 63.3 \mathrm{kDa}$ and $54.6 \mathrm{kDa}$ in case IrOMP which were not observed in IsOMP of the same isolates. The findings were similar with the findings of Borkowska-Opacka and Kedrak (2002) ${ }^{[11]}$ who reported high molecular weight protein fraction of 102 to 104 $\mathrm{kDa}$ in bovine strain of Pasteurella multocida when grown on iron-chelated medium. Zhao et al. (1995) ${ }^{[14]}$ reported high molecular protein fraction of $74 \mathrm{kDa}, 82 \mathrm{kDa}, 99 \mathrm{kDa}$ and 109 $\mathrm{kDa}$ in porcin strain of $P$. multocida grown in iron restricted medium. The variation in number and size of bands with other worker might be due to strain variation and growth condition of organism (Chawak et al., 2001) ${ }^{[15]}$.

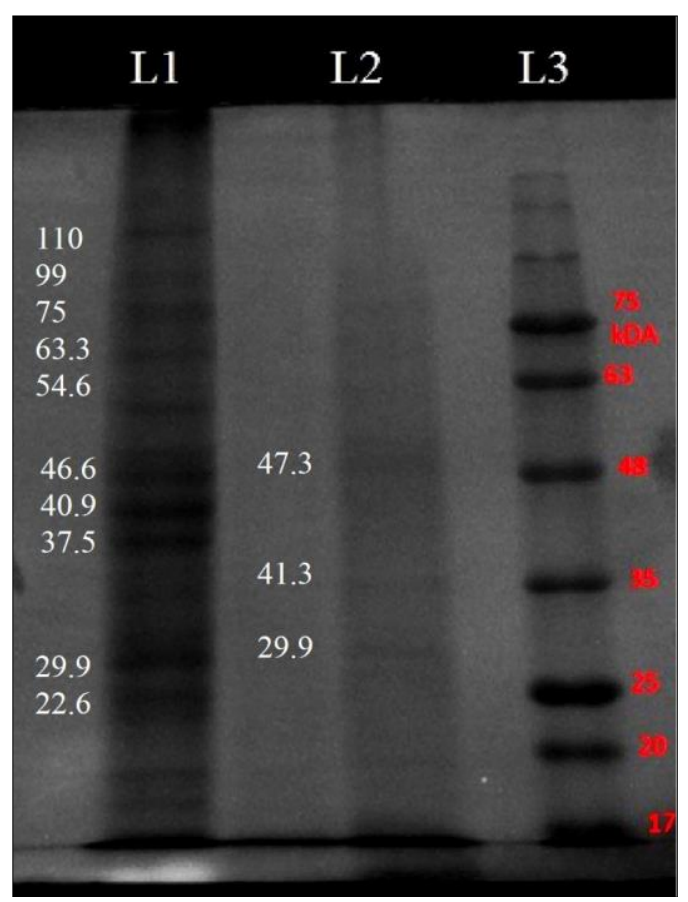

Fig 1: Electrophoretic profiles of the OMPs of $P$. multocida serotype A (Lane $1=$ Cells grown in BHIB with Dipyridyl, Lane $2=$ Cells grown in BHIB alone, Lane 3= Molecular weight standards.)

\section{Conclusion}

The extracted OMPs from P. multocida type A of pig origin grown in iron restricted and in iron sufficient media were found to be consisted of variable no. of proteins with different molecular sizes. Growth of the isolate under the influence of iron chelating agents could favour the expression of high molecular weight protein $(110 \mathrm{kDa}, 99 \mathrm{kDa}, 75 \mathrm{kDa}, 63.3$ $\mathrm{kDa}$ and $54.6 \mathrm{kDa}$ ). 


\section{Acknowledgement}

Authors acknowledge the ICAR All India Network Project on Haemorrhagic Septicaemia, Department of Microbiology, College of Veterinary Science, Assam Agricultural University, Khanapara for providing the $P$. multocida strain from their repository.

\section{References}

1. Harper M, Boyce JD, Adler B. Pasteurella multocida pathogenesis: 125 years after Pasteur. FEMS Microbiology Letters. 2006; 265(1):1-10.

2. Martin CBG, Ferri EFR. In vitro susceptibility of Pasteurella multocida subspecies multocida strains isolated from swine to 42 antimicrobial agents. Zentralbl Bakteriol. 1993; 279(3):387-393.

3. Srivastava SK. Immunogenicity of Pasteurella multocida grown in iron-restricted medium. J. Appl. Anim. Res. 1998; 13(1-2):137-144.

4. Wooldridge KG, Williams PH. Iron uptake mechanism of pathogenic bacteria. FEMS Micro. Rev. 1993; 12(4):325348.

5. Neilands JB. Siderophores. Arch. Biochem. Biophys. 1993; 302(1):1-3.

6. Veken JW, Shah NH, Klasssan P, Oudega B, Graaf FK. Binding of host iron-binding proteins and expression of iron-regulated membrane proteins by different serotype of $P$. multocida causing haemorrhagic septicaemia. Microbiol Pathogenesis. 1996; 21:59-64.

7. Collines $\mathrm{CH}$, Lyne PM. Microbiological methods. Laboratory techniques series, $4^{\text {th }}$ Edn., Butterworths, London, 1970

8. Kharb S, Charan S. Immunogenicity of iron-regulated outer membrane protein of Pasteurella multocida B:2 strain in mice model. Indian J. Ex. Biol. 2010; 48:11811187.

9. Laemmli UK. Cleavage of structural proteins during the assembly of the head of bacteriophage T4. Nature. 1970; 227:680-685.

10. Nagpal S, Sharma P, Singh A. Detection of Pasteurella multocda B:2 lipipolysaccharide and outer membrane protein specific antibodies in sheep and goat sera from Haryana and rajasthan. Vet. Pract. 2013; 14(2):199-203.

11. Borkowska-Opacka B, Kędrak A. Expression of ironregulated outer membrane proteins (IrOMPs) by Pasteurella multocida strains isolated from cattle. Bull. Vet. Inst. Pulawy. 2002; 46:157-164.

12. Choi-Kim K, Maheswaran SK, Felice LJ, Molitor TW. Relationship between the iron regulated outer membrane proteins and the outer membrane proteins of in vivo grown Pasteurella multocida. Vet. Micro. 1991; 28(1):75-92.

13. Zhang H, Ainsworth AJ, Montgomery RD. Use of a 35.5 $\mathrm{kDa}$ cell membrane composition of Pasteurella multocida and an anti-idiotype antibody to induce protective immunity in leghorn chickens. Vet. Microbiol. Immunopath. 1994; 41:89-100.

14. Zhao G, Pijoan C, Choi K, Maheswaran SK, Trigo E. (1995). Expression of iron-regulated outer membrane proteins by porcine strains of Pasteurella multocida. Can. J. Vet. Res. 1995; 59(1):46-50.

15. Chawak MM, Verma KC, Kataria JM. Characterization and immunizing properties of outer membrane protein of Pasteurella multocida grown in iron sufficient and iron restricted media. Indian J Comp. Micro. Imm. Infect. Dis. 2001; 22(1):36-42. 